\title{
НАВЧАЛЬНИЙ ДІАЛОГ У ПРОФЕСІЙНІЙ ПІДГОТОВЦІ МАЙБУТНЬОГО ВЧИТЕЛЯ ПОЧАТКОВОЇ ШКОЛИ
}

\author{
SVITLANA YATSENKO, Candidate of Pedagogical Sciences, \\ Associate Professor of Pedagogy, Zhytomyr Ivan Franko \\ State University, Ukraine
}

\section{THE ROLE OF EDUCATIONAL DIALOGUE IN THE PROFESSIONAL TRAINING OF A FUTURE PRIMARY SCHOOL TEACHER}

\begin{abstract}
У статті висвітлено теоретикометодичні аспекти використання навчального діалогу у професійній підготовці майбутнього вчителя початкової школи в руслі суспільних викликів щодо реформування освіти України. Обгрунтовано думку про необхідність оновлення змісту освіти у вищій школі, що забезпечить ефективність підготовки майбутніх фахівців до активної комунікації у вирішенні освітніх цілей та збагачення їх уміннями, необхідними для продуктивної організації діалогічного навчання в початковій школі. 3'ясовано, що навчальний діалог у цьому контексті слугує своєрідною формою міжособистісного спілкування, в якому відбувається обмін досвідом, відповідними знаннями та навичками двох комунікантів: суб'єктами виступають педагоги та учні (студенти). Окреслено роль інформаційного обміну у формі мовлення не тільки для збагачення учасників навчального діалогу новими знаннями, а й регулювання міжособистісних відносини. Доведено важливість навчального діалогу у процесі взаємодії суб'єктів освітнього процесу на засадах гуманності, свободи думки, толерантності, відвертості, що реалізує принципи педагогіки партнерства та уможливлює підвищення якості надання освітніх послуг здобувачам загальної середньої освіти. Наголошено на необхідності дотримання правил ведення діалогу та
\end{abstract}

(c) С. Яценко мовної поведінки комунікантів, зокрема вміння у логічній послідовності аргументовано відстоювати власну позицію, адекватно використовувати вербальні та невербальні засоби спілкування, розуміти, чути та слухати співрозмовника, виявляти толерантність до думок партнера тощо. Автор схвалює будь-які форми інтерактивної взаємодії у навчанні, в тому числі діалогові системи через онлайнвзаємодію користувачів. Основними умовами, що забезпечують ефективність професійної підготовки майбутніх педагогів до організації навчального діалогу в школі, визначено: використання діалогічних технологій, що забезпечують набуття досвіду професійної діяльності й розвиток професійних якостей; орієнтацію викладача на особистісні досягнення студентів; надання кожному 3 них можливості вільного вибору форм зворотного зв'язку й забезпечення психологічного комфорту в опануванні фахом; психолого-педагогічне супроводження дій майбутніх педагогів в освітньому процесі.

Ключові слова: навчальний діалог, початкова школа, професійна підготовка, майбутній педагог, освітній процес, заклад вищої освіти.

Summary. The article deals with theoretical and methodological aspects of the use of educational dialogue in the vocational training of a future elementary school teacher in the context of public challenges in reforming the education of
Ukraine. The author emphasizes the need to update the content of higher education in order to train future professionals for active communication while reaching educational goals and at the same time enriching them with skills necessary for the effective organization of dialogic education in primary schools. It is substantiated that the educational dialogue is a kind of interpersonal communication involving an exchange of experience, relevant knowledge and skills, when two communicators are involved: the subjects are teachers and students (students). It has been found out that information exchange in the form of communication helps not only enrich the participants of the educational dialogue with new knowledge, but also regulates relations between them, promotes relevant upbringing and development. The importance of educational dialogue between subjects of the educational process on the basis of humanity, freedom of thought, tolerance, openness and pedagogy of partnership, which makes it possible to improve the quality of the provision of educational services to students of general secondary education has been proved. The need to follow the rules of dialogic and linguistic behavior of communicators, including the ability in logical sequence to argue their position, adequately use verbal and nonverbal means of communication, understand, hear and listen to the interlocutor, to show tolerance were 
emphasized. The author approves of all forms of interactive interaction in training, including dialogic systems via online interaction. The basic conditions for the effectiveness of professional training of future teachers for the organization of educational dialogue at school are defined: the use of dialogic technologies that provide students with the experience of professional activity and the development of professional qualities; teachers' orientation on personal achievements of students; giving each student the freedom of choice, feedback, and comfort in mastering the profession; psychological and pedagogical support of future teachers' actions in the educational process.

Key words: educational dialogue, primary school, vocational training, future teacher, educational process, institution of higher education.

Мета: обгрунтувати теоретичні засади проблеми реалізації навчального діалогу та організаційні аспекти його використання у підготовці майбутнього вчителя початкової школи.

Постановка проблеми в загальному викладі. Перехід до постіндустріального (інформаційного) суспільства на тлі потужних євроінтеграційних процесів супроводжується впровадженням освітніх інновацій задля підвищення якості професійної підготовки педагога. Метою сучасної освіти в Україні визначено "всебічний розвиток людини як особистості та найвищої цінності суспільства, її талантів, інтелектуальних, творчих і фізичних здібностей, формування цінностей і необхідних для успішної самореалізації компетентностей", "підвищення освітнього рівня громадян задля забезпечення сталого розвитку України та її європейського вибору" (Закон "Про ocвimy", 2017). Зазначене актуалізує проблему не лише збагачення молодого покоління відповідними знаннями, уміннями чи навичками, а й, передусім, формування здатності до навчання впродовж життя, що характеризується творчою та продуктивною співпрацею 3 іншими, вміннями та навичками ефективної комунікації задля прийняття відповідальних рішень. Тому важливо сформувати діалогічну свідомість людини, навчити правилам ведення конструктивного діалогу для вирішення освітніх завдань, підготувати педагога до організації навчального діалогу, починаючи зі школи I-го ступеня зокрема, та інноваційної діяльності загалом.

Власне інноваційну компетентність сучасного педагога вбачають в його здатності використовувати кращі європейські освітні технології у професійній практиці. Динамічність змін в освіті в умовах їï інтегрування у світовий освітній простір висуває перед педагогами нові виклики - бути готовими до ефективного виконання своїх професійних функцій з урахуванням інноваційності (Budnyk, 2019).

Аналіз досліджень і публікацій. Проблеми розвитку професійнопедагогічної культури вчителя висвітлено в наукових дослідженнях О. Дубасенюк, Л. Карпової, Н. Кузьміної, Л. Пуховської, О. Савченко та ін. Методологічні підходи до вивчення інноваційної компетентності вчителя стали предметом дослідження I. Гавриш, І. Дичківської, О. Ігнатович, О. Мариновської, В. Сластьоніна, О. Шафран та ін. Педагогічна етика аналізувалася такими вченими, як Г. Васянович, І. Зязюн, педагогічне спілкування - О. Бодальов, I. Зимня, В. Кан-Калик, М.Нікандрова, М. Савчин, комунікативна компетентність педагога Н. Бабич, Г. Золотова, Л. Паламар, О. Семеног та ін., комунікативна компетнтність учителя початкових класів - В. Бадер, М. Вашуленко, Т.Грітченко, В. Усатий та ін.

У працях Б. Ананьєва, А. Леонтьєва, Б. Ломова та ін. висвітлено теоретичні аспекти комунікативної компетентності як здатності особистості до встановлення взаємовідносин, специфічну форму активності суб'єкта. Адже у процесі комунікації відбувається засвоєння певних цінностей, досвіду, розвиток особистості як суб'єкта діяльності. Питання використання навчального діалогу в освітньому процесі відображені у працях таких вітчизняних науковців, як А.Алексюк, В. Вихрущ, Л. Вовк, І.Глазкова, Г. Іванюк, Л. Петровська та ін.

Виклад основного матеріалу дослідження. Проблема суб'єктсуб'єктної взаємодії, навчального діалогу в освітньому процесі потребує глибинного аналізу у руслі філософії освіти, соціальної та педагогічної психології, професійної освіти, дидактики тощо.

Звернемося до наукових міркувань Г. Васяновича, який здійснив методологічне обгрунтування людської комунікації, зокрема у сфері освіти, в межах теорії екзистенціалізму. На думку вченого, "спілкування в суспільстві, колективі має більш кількісний, ніж якісний характер, тому сфера, в якій перебуває індивід, спонукає останнього до "закриття" душі. Тому індивід - це анонім, на свідомість якого тисне і соціальне, і власне, тим самим не даючи можливості йому розкрити себе у повну людську силу. Звідси випливає висновок, що спілкування стає формалізованим, несправжнім, йому притаманні лукавство, фальшивість, нещирість тощо. Така ситуація знецінює сенс життя, людське існування набуває абсурдності. Якщо абстрагуватися від абсолютизації цієї думки, що отримала всебічне обгрунтування у А. Камю, то можна визнати, що сьогодні це справді одна 3 нагальних проблем для педагогічного дослідження. Адже очевидно, що якість спілкування у студентських колективах, спілкування між педагогами, педагогами і студентами безпосередньо впливає на їх буття, на здобуття майбутньої професії, врешті, на становленняцілісної особистості" (Васянович, с. 15-16). Ці тези є вагомими для організації навчального діалогу, який базується на свободі думки, толерантності, відвертості, партнерстві.

На думку I. Беха, особистість за своєю структурою є утворенням "діалогічним", продуктом індивідуального досвіду спілкування і стосунків з іншими людьми. Домінантною педагогічних міркувань вченого є положення про те, що "повноцінний процес спілкування завжди є взаємодією конкретних особистостей, які певним чином ставляться одна до одної. Така закономірність спілкування й стала продуктивним підгрунтям доцільно організованої виховної діяльності педагога" (Бех, 2015, c. 247).

Навчальний діалог - своєрідна форма міжособистісного спілкування, в якому відбувається обмін досвідом, відповідними знаннями, 
вміннями та навичками. У діалозі,зазвичай, беруть участь два комуніканти, в освітньому процесі його суб'єктами є педагоги (викладачі) та учні (студенти). Така взаємодія слугує засобом активізації пізнавальної діяльності в умовах створеної навчальної ситуації. Інформаційний обмін у формі мовлення допомагає не лише збагатити учасників навчального діалогу новими знаннями, а й регулювати відносини між ними, сприяти гуманізації процесу навчання, виховання та розвитку.

У педагогічному контексті навчальний діалог - це спеціальна форма взаємодії учасників освітнього процесу, в якій відбувається зближення, взаємозбагачення і з'ясування різних позицій на рівноправних засадах (Крівщенко, 2017, c. 125).

Варто зауважити, що саме у початковій школі надзвичайно важливим є застосовування різноманітних форм діалогічного навчання учнів, що уможливлює швидку соціалізацію та налагодження ефективної комунікативної діяльності в класі. При цьому вчитель зазвичай практикує діалог фронтально, на рівні обміну запитаннями і відповідями вчителя 3 усіма учнями. За таких обставин педагог зорієнтований на отримання колективного результату навчання. Водночас часто практикують навчальні діалоги у формі "ученьучитель", "учень-учень", які характеризують індивідуальну активність кожного у спілкуванні.

Зміна домінантної функції вчителя з інформативної (викладання) до фасилітитивної (педагогічної підтримки) детермінує вдосконалення професійної підготовки й уточнення показників готовності до організації навчання на основі діалогу. У цьому контексті, як зауважує Г. Іванюк, здатність і готовність майбутнього вчителя початкової школи до педагогічної підтримки учнів у діалогічній взаємодії, пошуку цікавих і життєво важливих питань для обговорення полягає в наступному: умінні розпізнавати, діагностувати, прогнозувати проблему, що становить особистісний інтерес; використовувати проблему як засіб створення умов для формування знань, умінь, навичок, способів діяльності й уміти ними управляти, а саме: визна- чати пріоритети щодо особистісно центрованих завдань; використовувати ресурс навчання як засіб самостійного вирішення здобувачем освіти відповідних завдань (Іванюк, 2017, с. 254).

Діалог слугує дієвим засобом "переведення" професійної підготовки на особистісно-смисловий рівень, зауважує М. Кондрашов. За автором, реалізація діалогічного підходу в професійній підготовці та управлінні його якістю потребує чіткого уявлення про сутність діалогу, що часто трактується як мовлення, форма спілкування, комунікація, взаємне висловлювання як прояв психічної активності. Основою діалогу визначають відношення "Я - інший", що має такі складові: Я - Інший - С тосунки. У цій тріаді провідне значення мають власне взаємини, які стимулюють створення нової єдності - простору смислів діалогічної події (Кондрашов, 2019, с. 359).

У підготовці вчителя важливо акцентувати увагу на основних аспектах організації діалогічного навчання учнів у класі. Передусім, йдеться про правила ведення діалогу та мовну поведінку суб'єктів освітнього процесу, вміння у логічній послідовності аргументовано відстоювати власну позицію, адекватно використовувати вербальні та невербальні засоби спілкування, розуміти, чути та слухати співрозмовника, виявляти толерантність до думок партнера тощо. Адже у педагогічному спілкуванні реалізуються відповідні функції, що забезпечують досягнення освітньої мети: контактна, інформаційна, спонукальна, координаційна, пізнавальна, емотивна, встановлення відносин, впливова (Васянович, 2010, с. 374-375). Варто також ураховувати, що "спілкування в освітньому процесі може бути як деструктивним (коли дорослий маніпулює, навіює, змушує до чогось дитину), так і конструктивним" (Бех, 2015, c. 247).

I. Бех вважає, що педагогові необхідно володіти високим рівнем психологічної культури, основні положення якої можна звести до наступних вимог:

знати психологію школяра та правильно оцінювати його індивідуальні якості;

емоційно адекватно відгукува- тися на поведінкові реакції та актуальні психічні стани учня;

вибирати такий спосіб поведінки стосовно кожної особистості, який би відповідав іiї індивідуальним особливостям (Бех, 2015, с. 248).

Не випадково освітній процес, що реалізується через спеціально організоване спілкування, розглядають на трьох рівнях: на рівні соціального пізнання, емоційного ставлення та на поведінковому рівні (Там само).

Зазначене зумовлює використання у вищій школі навчального діалогу для підвищення комунікативної культури майбутніх учителів, що передбачає, зокрема, використання в процесу підготовки майбутніх учителів початкових класів навчальної дискусії.

У науково-методичній літературі практикують такі етапи підготовки та проведення навчальної дискусії: 1) підготовка (вибір форми дискусії, моделювання завдань, питань, проблем, правил поведінки, підготовка матеріального забезпечення); 2) проведення: початок дискусії (постановка проблеми, умови організації, правила поведінки, регламент); розташування учасників, розподіл їх на групи (якщо це необхідно), обговорення проблеми, дискусія (конкретні питання й відповіді, повідомлення та розгорнуті доповіді, залежно від обраної форми дискусії), надання результатів обговорення аудиторії, формулювання висновків та ухвалення рішення; 3 ) аналіз та узагальнення (вихід із гри, аналіз, оцінювання результатів роботи всієї групи та самооцінка) (Романко, 2007).

У сучасній практиці вищої школи навчальний діалог доцільно використовувати як засіб активізації пізнавальної діяльності майбутніх фахівців. Так, на лекціях часто застосовують такі прийоми, як "створення інформаційного розриву", "виявлення протилежних думок", "застосування дискусійних елементів", "залучення до вирішення проблемних ситуацій" тощо. Наприклад, при висвітленні нового матеріалу викладачеві доцільно розвивати критичне мислення студентів, здатність до аналізу отриманої інформації, тому варто практикувати їх залучення до пошуку суперечливих позицій щодо тієї чи 
іншої проблеми, що і $є$ предметом обговорення. Для цього учасники освітнього процесу мають навести якомога більше аргументів-доказів 3 приводу істинності однієї позиції і хибності іншої, і навпаки. Водночас ці думки необхідно спростувати у формі діалогу. Це розвиває навички наукової комунікації, вміння аналізувати проблему у контексті їі багатоаспектності 3 урахуванням позитивних і негативних ознак (характеристик).

Ефективним також є прийом "створення інформаційного розриву", сутність якого полягає в тому, що викладач на занятті навмисно вилучає якусь цінну інформацію, а студенти мають виявити цей момент у мовленні лектора, відповідно за допомогою низки запитань i відповідей отримати необхідну інформацію, тобто відшукати " інформаційний розрив" у логіці викладу навчального матеріалу. Це стимулює уважність, активність, вміння слухати, аналізувати, брати участь у навчальному діалозі тощо.

Важливого значення набуває навчальний діалог і для оцінювання результатів освітньої діяльності. Як засвідчує фінський досвід, "оцінювання - це діалог і обов'язковий зворотний зв'язок між учителем, учнем та батьками, і він має бути спрямований на перспективу" (Головіна, 2019). Власне у Новій українській школі пропагується педагогіка партнерства, що значною мірою стосується й результатів навчання, адже йдеться про особистісний розвиток кожного учня (студента), формування в нього почуття власної гідності, самоповаги, впевненості у своїх знаннях, здатності до самопізнання й саморозвитку.

Заслуговують на увагу і принципи оцінювання у фінських школах, а саме: оцінювання є рівним; потребує відкритості, співпраці та участі учнів; має бути систематичним і послідовним, різноманітним і систематичним; грунтується на цілях і критеріях; враховує вік і здібності учня (Головіна, 2019) та ін., що $\epsilon$ беззаперечно актуальним і для вітчизняної системи освіти. Безумовно, труднощі його запровадження зумовлені ментальними особливостями, відсутністю досвіду психолого-педагогічної комунікації та правил ведення діалогу в процесі навчання та оцінювання його результатів. Водночас цілком правомірним видається все частіше застосовування в освітньому процесі взаємоперевірки, роботи в парах, малих групах, що розвиває в учнів (студентів) навички діалогічного навчання.

Ефективними формами організації навчального діалогу є групова робота, уроки-діалоги, проблемне навчання та ін. При цьому особливо важливим $є$ дотримання вимог щодо характеру запитань учителя, які мають спонукати учнів не тільки до виявлення раніше засвоєних знань, а й розкриття сутності навчальної проблеми.

Підготовка вчителя до організації навчального діалогу з молодшими школярами передбачає залучення студентів до різноманітних видів активності 3 елементами тренінгів, наприклад, підготовку завдань (класних, домашніх) та організацію самоперевірки. Така робота сприяє формуванню готовності до взаємодії у парі, малій групі, колективі. Включення учасників освітнього процесу у творчу діяльність забезпечує їх мовномовленнєвий розвиток, стимулювання інтересу до пізнавальної діяльності. Створення ситуацій спільних переживань сприяє підготовці вчителя до педагогічної взаємодії. Такі ситуації варто наближати до діяльності учнів, об'єднаних спільною метою, що надає діалогічній взаємодії позитивних емоцій (Іванюк, 2017, с. 259).

У сучасній освіті все частіше використовуються інформаційнокомунікаційні технології для оптимізації та підвищення її якості, в тому числі, й для обміну інформацією між користувачами. Відповідно популяризуються різноманітні форми навчального діалогу онлайн. У закладах освіти зарубіжжя цей метод навчання є досить поширеним. Як засвідчують сучасні наукові дослідження, вчені пропонують гібридний метод навчання для вирішення освітніх завдань, діалогові системи через онлайн-взаємодію користувачів. При цьому автори пропонують різні варіанти діалогу для офлайн та онлайн навчання (Liu, Tur, Hakkani-Tur, Shah, Heck, 2018). Елементи навчального діалогу сьогодні широко використовують для дистанційного навчання в Україні, оскільки результати освітньої діяльності потребують належного зворотнього зв'язку, а значить, - обміну інформацією, ефективного педагогічного спілкування.

Таким чином, підвищення рівня підготовки студентів до професійної діяльності значною мірою залежить від застосування діалогічного підходу. Основними умовами, що забезпечують його ефективність, $є$ : використання діалогічних технологій, що забезпечують набуття студентами досвіду професійної діяльності й розвиток професійних якостей; створення діалогічної ситуації в освітньому процесі; орієнтація викладача на особистісні досягнення студентів; забезпечення вільного вибору, зворотного зв'язку й психологічного комфорту в процесі навчання; психолого-педагогічний супровід майбутніх педагогів тощо (Кондрашов, 2019, с. 361).

Висновки та перспективи подальших досліджень. Реформування сучасної освіти передбачає, передусім, відхід від традиційних методик викладання, в основі яких - пояснювально-ілюстративне навчання, що зводиться до відтворення учнями навчально-пізнавальної інформації. Натомість педагогічна інноватика грунтується на інтерактивних формах взаємодії учасників освітнього процесу, серед яких чільне місце відводиться навчальному діалогу. Діалог - це нові вимоги до взаємодії у системі "викладач - студенти", "вчитель - учні" на засадах толерантності, що заперечує установку на знищення позиції іншого. Діалог є формою духовної комунікації, коли смислові позиції його учасників не просто доповнюють один одного, а створюють єдине ціле, яке не можна звести до простої суми різних поглядів, суджень, роздумів (Кондрашов, 2019, с. 359). Тому на часі впровадження інновацій у професійну підготовку майбутніх учителів початкової школи для підготовки їх до активної комунікації у вирішенні освітніх цілей i, водночас, збагачення компетентностями, що уможливлюють ефективну організацію діалогічного навчання в початковій школі на засадах гуманності та педагогіки партнерства, підвищення якості надання освітніх послуг здобувачам загальної середньої освіти. 
Перспективи подальших наукових пошуків вбачаємо у дослідженні психологічних механізмів організації діалогічного навчання в закладах освіти різних типів, а також розроблення навчально-методичних комплексів для різних освітніх галузей з використанням методик діалогічного навчання, в тому числі освітньої комунікації онлайн.

\section{СПИСОК ЛІТЕРАТУРИ}

Бех, I. (2015). Вибрані наукові праці. В 2-х т. Т. 1. Виховання особистості. Чернівці: Букрек. 840 с.

Васянович, Г. П. (2010). Вибрані твори: в 5-ти т. Т.3: Педагогічна етика: навчальний посібник. Львів: Сполом.

Васянович, Г. (2013). Методологічні контексти педагогічної науки на сучасному етапі її розвитку. Педагогіка і психологія професійнӧ̈ освіти, 3, 9-30. URL : h t t p : // n buv.gov.ua/UJRN/ Pippo 201333

Головіна, О. (2019). Оцінювання - це навичка і завжди діалог. Фінський досвід. Сайт НУШ. URL: https://nus.org.ua/articles/ otsinyuvannya-tse-navychka-izavzhdy-dialog-finskyj-dosvid/

Закон України "Про освіту" (Відомості Верховної Ради) (2017). URL: http://zakon5.rada.gov.ua/ laws/show/2145-19.

Іванюк, Г. (2017). Підготовка вчителя початкової школи до діалогічного навчання в контексті розбудови Нової української школи. Педагогічні науки: теорія, історія, інноваційні технології. № 6 (70). С. 252-262. DOI 10.24139/2312-5993/ 2017.06/252-262

Кондрашов, М. М. (2019). Діалогічний підхід до навчання як засіб якісної підготовки майбутніх фахівців до професійної діяльності. Науковий вісник Льотної академії. Серія: Педагогічні науки. № 5. С. 357-362.
Крівшенко, Л. М. (2017). Навчальний діалог - провідна складова евристичної освіти. Педагогічні науки. Вип. 133. С. 115-128.

Романко, I. (2007). Діалог вчителя і учнів як основа взаєморозуміння в освітніх закладах Великої Британії. URL: http:// elib.umsa.edu.ua/jspui/bitstream/ $\mathrm{u} \mathrm{m} \mathrm{s} \mathrm{a} \mathrm{/} 69599 / 1 /$ Dialoh_vchytelia_i_uchniv.pdf

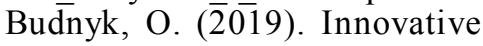
Competence of a Teacher: best European Practices. Journal of Vasyl Stefanyk Precarpathian National University, No. 6(1). P. 76-89. DOI: 10.15330/jpnu.6.1.76-89.

Liu, B., Tur, G., Hakkani-Tur, D., Shah, P., Heck, L. (2018). Dialogue Learning with Human Teaching and Feedback in End-to-End Trainable Task-Oriented Dialogue Systems. Proceedings of the 2018 Conference of the North American Chapter of the Association for Computational Linguistics: Human Language Technologies, New Orleans, Louisiana. Vol. 1. P. 2060-2069. DOI 10.18653/v1/N18-1187. URL: https:// www.aclweb.org/anthology/N18$1187 /$

\section{REFERENCES}

Bekh, I. (2015). Vybrani naukovi pratsi. V 2-kh t. T. 1. Vykhovannia osobystosti. Chernivtsi: Bukrek. 840 s.

Vasianovych, H. P. (2010). Vybrani tvory: v 5-ty t. T.3: Pedahohichna etyka: navchalnyi posibnyk. Lviv: Spolom. $420 \mathrm{~s}$.

Vasianovych, H. (2013). Metodolohichni konteksty pedahohichnoi nauky na suchasnomu etapi yii rozvytku. Pedahohika i psykholohiia profesiinoi osvity. № 3. S. 9-30. URL: h t t p : // n buv.gov.ua/UJRN/ Pippo_2013_3_3

Holovina, O.

(2019). Otsiniuvannia - tse navychka i zavzhdy dialoh. Finskyi dosvid. Sait
NUSh. URL: https://nus.org.ua/ articles/ot sin yuvan nya-tsenavychka-i-zavzhdy-dialog-finskyjdosvid/

Zakon Ukrainy "Pro osvitu" (Vidomosti Verkhovnoi Rady) (2017). URL: http://zakon5.rada.gov.ua/ laws/show/2145-19

Ivaniuk, H. (2017). Pidhotovka vchytelia pochatkovoi shkoly do dialohichnoho navchannia $v$ konteksti rozbudovy Novoi ukrainskoi shkoly. Pedahohichni nauky: teoriia, istoriia, innovatsiini tekhnolohii. № 6 (70). S. 252-262. DOI $10.24139 / 2312-5993 / 2017.06 / 252-262$

Kondrashov, M. M. (2019). Dialohichnyi pidkhid do navchannia yak zasib yakisnoi pidhotovky maibutnikh fakhivtsiv do profesiinoi diialnosti. Naukovyi visnyk Lotnoi akademii. Seriia: Pedahohichni nauky. № 5. S. 357-362.

Krivshenko, L. M. (2017). Navchalnyi dialoh - providna skladova evrystychnoi osvity. Pedahohichni nauky. Vyp. 133. S. 115-128.

Romanko, I. (2007). Dialoh vchytelia i uchniv yak osnova vzaiemorozuminnia $\mathrm{v}$ osvitnikh zakladakh Velykoi Brytanii. URL: http://elib.umsa.edu.ua/jspui/ bits trea m/umsa/6959/1/ Dialoh_vchytelia_i_uchniv.pdf

Budnyk, O. ( $\overline{2} 019)$. Innovative Competence of a Teacher: best European Practices. Journal of Vasyl Stefanyk Precarpathian National University, No. 6(1). P. 76-89. DOI: 10.15330/jpnu.6.1.76-89.

Liu, B., T?r, G., Hakkani-T?r, D., Shah, P., Heck, L. (2018). Dialogue Learning with Human Teaching and Feedback in End-to-End Trainable Task-Oriented Dialogue Systems. Proceedings of the 2018 Conference of the North American Chapter of the Association for Computational Linguistics: Human Language Technologies, New Orleans, Louisiana. Vol. 1. P. 2060-2069. DOI 10.18653/v1/N18-1187. URL: https:// www.aciwed.org/antiloiogy/ivio$1187 /$

Стаття надійшла 5.12.2019p. 